\title{
Control of Thyroglobulin Secretion in Patients with Ectopic Thyroid Gland
}

\author{
J. LEGER, A. TAR, M. SCHLUMBERGER, AND P. CZERNICHOW
}

Unité d'Endocrinologie Pédiatrique et Diabète (J.L., A.T., P.C.J, Hôpital des Enfants Malades, Paris; and Unité de Médecine Nucléaire [M.S.J, Institut Gustave Roussy, Villejuif, France

\begin{abstract}
Serum thyroglobulin (Tg) measurements were performed in 17 children with congenital hypothyroidism due to an ectopic thyroid gland before therapy and during follow-up. Data were analysed in four periods according to duration of therapy and compared to results obtained in a group of 51 normal children aged 1 month to 6 yr. At diagnosis serum Tg was higher than the mean normal value measured at a similar age. We observed a rapid and parallel decrease of both $\mathrm{Tg}$ and thyroid-stimulating hormone during the early weeks of therapy. However, $\mathrm{Tg}$ was always detectable in the serum of treated (euthyroid) patients. After 34 months of therapy serum $\mathrm{Tg}$ was $11.4 \pm 1 \mathrm{ng} / \mathrm{ml}$, a value significantly different $(p<$ 0.001) from that obtained in normal controls of similar age $(23.5 \pm 3 \mathrm{ng} / \mathrm{ml})$. In nine treated children aged more than $2 \mathrm{yr}$, thyroid-stimulating hormone and $\mathrm{Tg}$ were increased after a brief period of decreased L-thyroxine dosage. These data indicate that ectopic thyroid tissue does not involuate during thyroxine therapy and, in response to elevations of serum thyroid-stimulating hormone, can be stimulated to secrete Tg. (Pediatr Res 23: 266-269, 1988)
\end{abstract}

\section{Abbreviations}

Tg, thyroglobulin

TSH, thyroid stimulating hormone

T3, triiodothyronine

TRH, thyrotropin releasing hormone

T4, thyroxine

FT4, free T4

RIA, radioimmunoassay

$\mathrm{Tg}$ is secreted by the thyroid gland and its presence in the serum indicates that some thyroid tissue is present (1). In patients with congenital hypothyroidism there is a good correlation between the presence of thyroid tissue and the presence of $\mathrm{Tg}$ in serum. Infants with athyreosis have undetectable serum $\mathrm{Tg}$, whereas in those with thyroid tissue as demonstrated by thyroid scanning, $\mathrm{Tg}$ is present in serum $(2,3)$. In a group of patients with congenital hypothyroidism and remnant thyroid tissue, the mean $\mathrm{Tg}$ value was higher than normal values for age (3). $\mathrm{Tg}$ secretion is subject to TSH control. In normal subjects, suppression of pituitary TSH release by $\mathrm{T} 3$ decreases serum Tg levels (4), whereas TSH stimulation by TRH increases serum Tg levels (5). Thus, elevated serum $\mathrm{Tg}$ values observed in some patients with ectopic gland may be due to over stimulation by TSH of remnant tissue.

Received June 23, 1987; accepted October 27, 1987.

Reprint requests Dr. J. Leger, Unité d'Endocrinologie Pédiatrique et Diabète, Hopital des Enfants Malades, 149 Rue de Sèvres 75015 Paris, France.
Herein we measured serum $\mathrm{Tg}$ during the period of early treatment and control of the hypothyroid state and also later, after a short period of decreased thyroxine dosage. Our results indicate that $\mathrm{Tg}$ secretion by the ectopic gland is under the control of TSH and resembles that observed in the normal gland. Detectable serum $\mathrm{Tg}$ in treated (euthyroid) patients suggests that some thyroid hormone secretion occurs even in patients in good control and after a long period of treatment.

\section{PATIENTS AND PROTOCOL}

A group of 17 children with ectopic thyroid glands was enrolled in this study. They were selected from a cohort of patients with congenital hypothyroidism on the basis of the radioiodine uptake $\left.{ }^{123} \mathrm{I}\right]$ and the presence of measurable serum Tg. All had measurable $\mathrm{Tg}$ levels when evaluated during the first weeks of life, before L-thyroxine replacement therapy. Treatment usually was initiated before 1 month of age (range 20-45 days, mean \pm SEM $27 \pm 2$ days) and the patients were seen at regular intervals for evaluation. Sera for $\mathrm{Tg}$ measurements were kept at $-20^{\circ} \mathrm{C}$ until assay. Data were grouped in four periods according to the timing of thyroxine therapy -2 wk to 2 months, 2 to 10 months, 10 to 34 months, and more than 34 months.

In a separate group of nine patients (with ectopic glands) who had received adequate thyroxine therapy for more than $2 \mathrm{yr}$, the effect of a decrease of $\mathrm{T} 4$ dosage on the serum $\mathrm{Tg}$ levels was analyzed. All patients had measurable Tg levels when assayed at 1 month of age before beginning therapy. Serum Tg, TSH, and FT4 were measured during adequate T4 therapy (period A) and after 6 wk of $(50 \%)$ reduced thyroxine dosage (period B). Informed consent was obtained from the parents for this second protocol.

A group of 51 children aged 1 month to $6 \mathrm{yr}$, entering the department of pediatric surgery for minor operations, served as controls. Blood $(2 \mathrm{ml})$ was taken at least 1 day before surgery at the time of routine laboratory studies after consent of the parents was obtained.

\section{METHODS}

Serum $\mathrm{Tg}$ was measured by RIA using the method of Van Herle et al. (4). The lower limit of sensitivity was $2.5 \mathrm{ng} / \mathrm{ml}$. The presence of circulating $\mathrm{Tg}$ antibodies was ruled out by the tanned red cell agglutination technique (Burroughs-Wellcome Research, Triangle Park, NC). Serum T4, FT4, and TSH concentrations were measured by RIA using commercial kits. As indicated, TSH was measured by two techniques. The RIA technique was used for the first part of the study, whereas an immunoradiometric assay (6) was used for the second part of the study concerning variation of the thyroxine treatment dosage in older children.

All data are reported as mean \pm SEM. Statistical comparisons 
were made by Student's paired and unpaired $t$ tests, or by linear regression analysis.

\section{RESULTS}

Serum T4, T3, TSH, and Tg levels at the time of diagnosis are shown in Figure 1. The mean serum $\mathrm{Tg}$ was higher than the mean normal value measured at a similar age although this difference was not significant $(98.3 \pm 32.8$ versus $55.3 \pm 6.7 \mathrm{ng} /$ $\mathrm{ml}$ ). Before treatment no correlation was found between $\mathrm{Tg}$ and TSH, T4, or T3.

Mean values for serum Tg and TSH levels in treated patients for the several treatment intervals are shown in Table 1 and are represented in percent of initial value in Figure 2. Serum T4 increased with treatment and mean values remained in the high normal range. It can be seen that TSH decreased rapidly and became normal after 2 months of therapy. A parallel decrease in serum $\mathrm{Tg}$ was observed although the rate of decline was slower than the fall of serum TSH. After 2 months of therapy the mean serum $\mathrm{Tg}$ level was significantly lower than the mean value of normal control children. Serum Tg remained detectable in the serum of treated children at all treatment intervals.

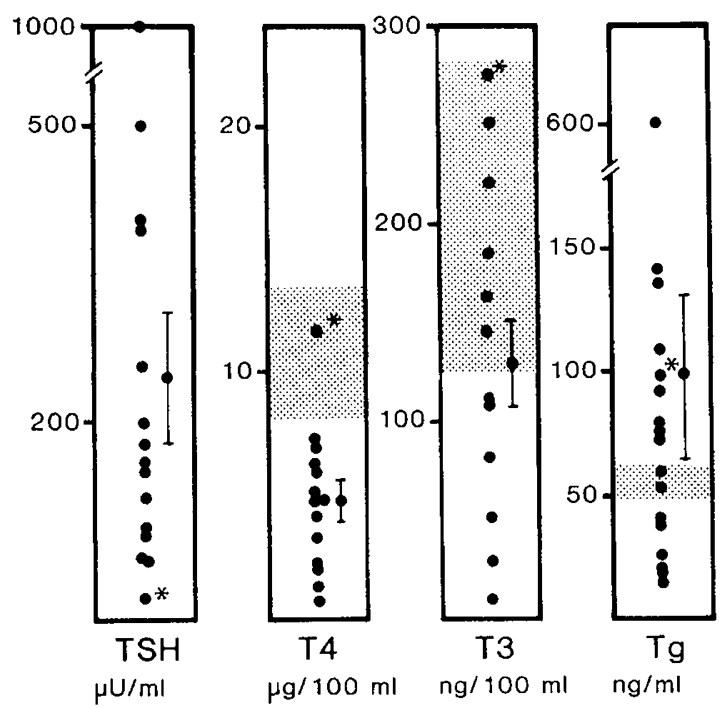

Fig. 1. Serum TSH, T4, T3, and Tg at time of diagnosis. In one case identified by an asterisk serum T4 was in the normal range. However, serum TSH was elevated and thyroid scanning revealed a large ectopic thyroid gland in this infant.
The data concerning reduction of thyroxine dosage in older treated children are shown in Figure 3. A significant fall in serum FT4 was observed (from $24 \pm 1.9$ to $16 \pm 0.6 \mathrm{ng} / 1, p<0.01$ ). Serum TSH increased during the same period (from $5.3 \pm 1.8$ to $39 \pm 7 \mu \mathrm{U} / \mathrm{ml}, p<0.01$ ) and there was an increase in serum $\mathrm{Tg}$ from $13.2 \pm 1.5$ to $24.1 \pm 4 \mathrm{ng} / \mathrm{ml}(p<0.05)$. There was no correlation between the magnitude of the decrease in serum T4 and the rise in serum TSH or the rise of serum $\mathrm{Tg}$.

\section{DISCUSSION}

The aim of this investigation was to assess the changes in serum $\mathrm{Tg}$ in a group of infants with ectopic thyroid glands during treatment. The mean serum $\mathrm{Tg}$ level was elevated above the normal value for age at the time of diagnosis although the elevation was not significant. During L-thyroxine therapy a gradual decline of serum $\mathrm{Tg}$ values was observed and this decline generally paralleled a progressive decrease in serum TSH concen-

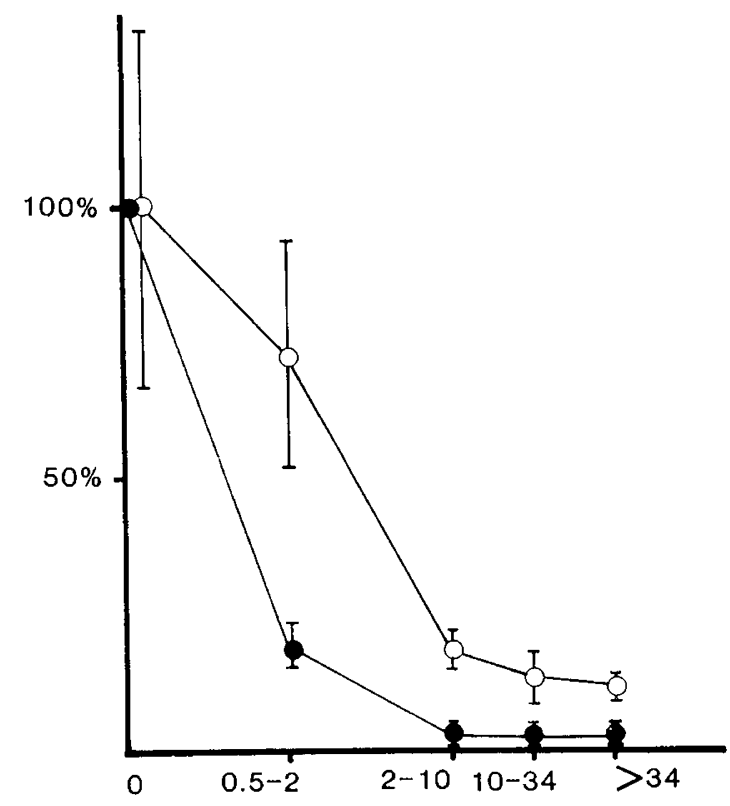

Fig. 2. Variation of serum TSH $(\bullet)$ and $\mathrm{Tg}(\mathrm{O})$ in children with congenital hypothyroidism during thyroxine therapy. Values on the vertical axis are expressed in percent of initial value at the time of diagnosis. The intervals of treatment in months are shown on the horizontal axis.

Table 1. Serum TSH, FT4, and Tg concentrations* during several intervals of treatment in 17 children with congenital hypothyroidism due to ectopic thyroid glands [mean $\pm S E M(n)]$

\begin{tabular}{|c|c|c|c|c|c|}
\hline & \multirow{2}{*}{$\begin{array}{c}\text { Before } \\
\text { treatment* }\end{array}$} & \multicolumn{4}{|c|}{ Interval of therapy (mo) } \\
\hline & & $0.5-2$ & $2-10$ & $10-34$ & $>34$ \\
\hline TSH & $245 \pm 65$ & $48 \pm 11$ & $5.7 \pm 0.9$ & $4.5 \pm 1$ & $4.5 \pm 1.3$ \\
\hline$(\mu \mathrm{U} / \mathrm{ml})$ & (15) & $(9)$ & (11) & (8) & (10) \\
\hline $\mathrm{T} 4$ & $4.7 \pm 0.8$ & $12.4 \pm 0.7$ & $12.7 \pm 0.8$ & $13 \pm 0.9$ & + \\
\hline$(\mu \mathrm{g} / 100 \mathrm{ml})$ & (14) & $(9)$ & $(10)$ & (7) & \\
\hline $\mathrm{Tg}$ & $98.3 \pm 32.8$ & $71.8 \pm 20.7$ & $18.5 \pm 3.6+$ & $12.9 \pm 4.9$ & $1.4 \pm 1 \S$ \\
\hline$(\mathrm{ng} / \mathrm{ml})$ & (17) & (12) & (15) & (9) & (14) \\
\hline Controls & $\begin{array}{c}55.3 \pm 6.7 \| \\
(12)\end{array}$ & & $33.5 \pm 4.4 \div$ & $\begin{array}{c}21.4 \pm 2.2 \\
(16)\end{array}$ & $\begin{array}{c}23.5 \pm 3 \S \\
(15)\end{array}$ \\
\hline
\end{tabular}

* Treatment was initiated before 1 month of age. After this period age and duration of treatment were considered to be identical.

$\dagger$ FT4 $(\mathrm{ng} / \mathrm{l})=23 \pm 1.5(n=13)$.

$\ddagger p<0.02$.

$\S p<0.001$.

\| Age of the control population for this period: 20 to 35 days. 

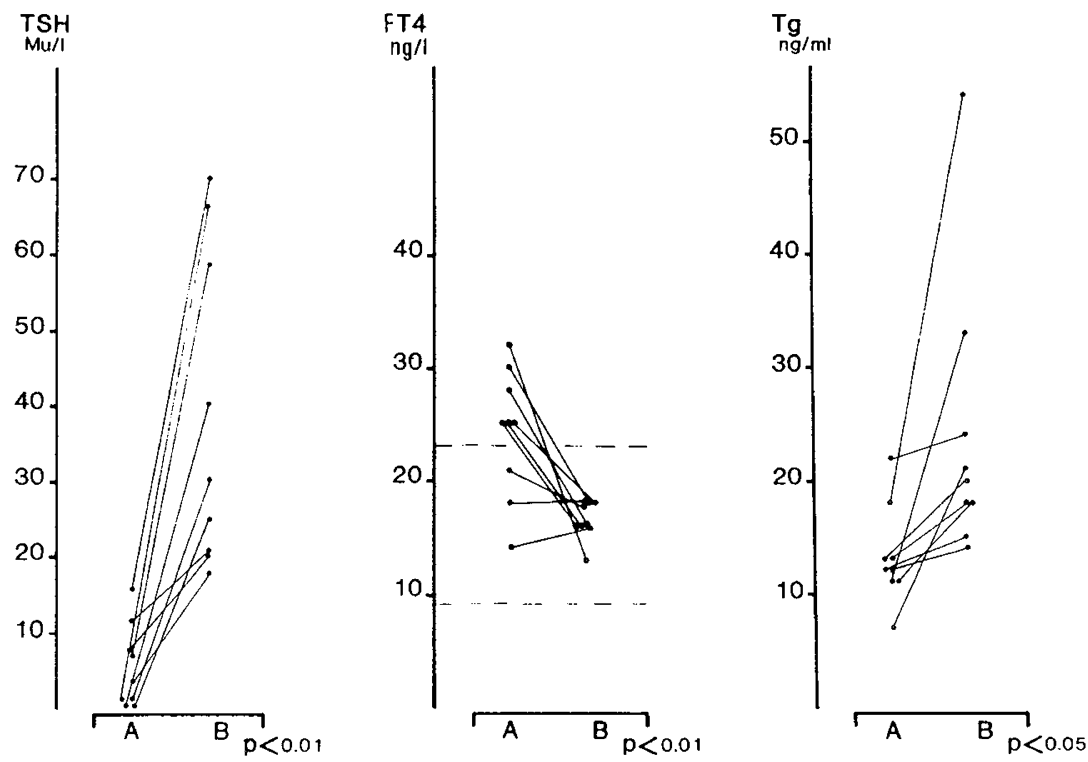

Fig. 3. Variation of TSH, FT4, and $\mathrm{Tg}$ in nine children during adequate thyroxine replacement therapy (period $A$ ) and after 6 wk of $50 \%$ decreased thyroxine dosage ( period $B$ ). The mean values for periods A and B differed significantly for each parameter.

trations. Although serum $\mathrm{Tg}$ was relatively decreased during thyroxine therapy it was never totally suppressed.

In a separate group of children, a transient $50 \%$ decrease in daily thyroxine dosage was instituted. In this situation the serum FT4 level decreased, and serum TSH increased. The mean serum $\mathrm{Tg}$ level increased significantly indicating the presence of responsive thyroid tissue. This result indicated that the residual ectopic thyroid tissue in these children can be stimulated when TSH is moderately elevated in the serum. In a study by Job et al. (7) the residual ectopic tissue in children with congenital hypothyroidism was sequentially studied by radioiodine uptake 1.5 to $3.5 \mathrm{yr}$ after diagnosis. On the basis of a progressive decline of iodine uptake these investigations concluded that there is a progressive involution of thyroid tissue. On the basis of our serum $\mathrm{Tg}$ measurements herein we reach a different conclusion.

As previously reported by several investigators $(2,3,8,9)$ serum $\mathrm{Tg}$ is elevated in patients with ectopic thyroid glands. The exact mechanisms for this high serum $\mathrm{Tg}$ is not clear. Serum $\mathrm{Tg}$ levels are related to several factors. The first is the concentration of circulating TSH. Serum TSH is elevated in the case of primary congenital hypothyroidism and probably is the primary factor responsible for the high serum $\mathrm{Tg}$ level $(10,11)$. However, we did not observe a significant correlation between the serum TSH and $\mathrm{Tg}$ levels in our children and such a correlation might be expected if TSH was the principal cause of the elevated serum $\mathrm{Tg}$. Other mechanisms should also be considered including the metabolic clearance rate of $\mathrm{Tg}$ and the rate of secretion by the thyroid gland. A decreased clearance of $\mathrm{Tg}$ may explain a high serum $\mathrm{Tg}$ level in hypothyroidism, but to our knowledge there are no data available on this point and we conducted no measurements of $\mathrm{Tg}$ clearance.

Herein, an increased rate of secretion by an ectopic tissue remnant remains a possible cause. It has been shown in patients with nontoxic goiter (12), in some cases of thyroiditis (13), and in some patients with benign and malignant thyroid tumors (14) that increased serum Tg levels may be observed in the absence of an elevated serum TSH. In this situation an increased rate of secretion of $\mathrm{Tg}$ by an abnormal tissue may be involved. A similar mechanism may operate in children with ectopic tissue. Furthermore it has been shown in premature neonates that serum $\mathrm{Tg}$ is elevated compared to term infants (15). One might speculate that the ectopic glands in our patients remained in a fetal state. Finally our findings may reflect abnormal secretion by dystrophic tissue or an abnormal developmental process in the ectopic glands. Although histological descriptions of these glands are scarce, available data show that tissue of ectopic thyroid is abnormal and dysplasic (16-18).

The decline of serum Tg during treatment is at least partly due to the decrease in serum TSH concentration. However, a gradual decline in $\mathrm{Tg}$ secretion also is observed during the first year of life in normal children (19). The extent to which our observations in hypothyroid infants reflect this normal process of progressive decline in serum $\mathrm{Tg}$ remains speculative. At the end of the first year of treatment and thereafter the mean serum $\mathrm{Tg}$ level was lower than the value in normal controls. The persistence of measurable serum $\mathrm{Tg}$ in treated patients suggests that thyroid secretion occurs to some extent in patients with treated congenital hypothyroidism (athyreosis excluded because of undetectable Tg level in these patients $(2,3,8,9)$. It has been shown that when thyroid tissue is totally suppressed the serum $\mathrm{Tg}$ level falls to undetectable levels. This can be demonstrated in patients with thyrotoxicosis factitia (20) in which cases complete suppression of thyroid function is associated with undetectable serum TSH levels, low radioiodine uptake, and undetectable serum $\mathrm{Tg}$ concentrations.

The situation is rather different in our group of patients. During the course of thyroxine therapy, dosage was adjusted to maintain serum TSH levels in a normal range, and the serum TSH level in these children was never undetectable. The ectopic tissue was therefore continuously stimulated, presumably accounting for the persistant measurable $\mathrm{Tg}$ serum levels. The concept of functioning remnant thyroid tissue is further emphasized by the secondary rise in serum $\mathrm{Tg}$ observed when the thyroxine replacement dose was reduced. This increase in serum $\mathrm{Tg}$ indicates that thyroid tissue was present in these children and, when stimulated, can secrete more $\mathrm{Tg}$ and possibly $\mathrm{T} 4$. Our results indicate that the serum $\mathrm{Tg}$ measurement can be a useful tool to evaluate residual thyroid function in patients with congenital hypothyroidism after treatment.

\section{REFERENCES}

1. Van Herle AJ, Vassart G, Dumont JE 1979. Control of thyroglobulin synthesis and secretion. N Engl J Med 301:239-249

2. Czernichow P, Schlumberger M, Pomarede R, Fragu P 1983. Plasma thyroglobulin measurements help determine the type of thyroid defect in congenital hypothyroidism. J Clin Endocrinol Metab 56:242-245

3. Léger J, Schlumberger M, Czernichow P 1986. Diagnostic étiologique de l'hypothyroidie congénitale et thyroglobuline plasmatique. Arch Fr Pediatr 43:179-182

4. Van Herle AJ, Uller RP, Matthews NC, Brown J 1973. Radioimmunoassay for measurement of thyroglobulin in human serum. J Clin Invest 52:1320- 
1327

5. Van Herle AJ, Vassart G, Dumont JE 1979. Control of thyroglobulin synthesis and secretion. N Engl J Med 301:307-314

6. Cobb WE, Lamberton RP, Jackson I 1984. Use of a rapid, sensitive immunoradiometric assay for thyrotropin to distinguish normal from hyperthyroid subjects. Clin Chem 30:1558-1560

7. Job JC, Canlorbe P, Tubiana M 1965. Decreasing radioiodine uptake during the course of congenital hypothyroidism. In: Cassans C, Andreali M (eds) Current Topics in Thyroid Research. Academic Press, New York, pp 82731

8. Osotimehim B, Black EG, Hoffenberg R 1979. Thyroglobulin concentration in neonatal blood: a possible test for neonatal hypothyroidism. $\mathrm{Br}$ Med J 2:1467-1468

9. Black EG, Bodder J, Hulse DA, Hoffenberg R 1982. Serum thyroglobulin in normal and hypothyroid neonates. Clin Endocrinol 16:267-273

10. Pezzino V, Filetti S, Belfiore A, Proto S, Donzelli G, Vigneri R 1981. Serum thyroglobulin levels in the newborn. J Clin Endocrinol Metab 52:364-366

11. Refetoff S, Lever EG 1983. The value of serum thyroglobulin measurement in clinical practice. JAMA 250:2352-2357

12. Feldt-Rasmussen U, Petersen PH, Date J, Madsen CM 1982. Serum thyroglobulin in patients undergoing subtotal thyroidectomy for toxic and non toxic goiter. J Endocrinol Invest 5:161-164
13. Smallridge RC, De Keyser FM, Vanherle AJ, Butkus NE, Wartofsky L 1986. Thyroid iodine content and serum thyroglobulin: cues to the natural history of destruction induced thyroiditis. J Clin Endocrinol Metab 62:1213-1219

14. Schlumberger M, Charbord P, Fragu P, Lumbroso J, Parmentier $C$, Tubiana M 1980. Circulating thyroglobulin and thyroid hormones in patients with metastases of differentiated thyroid carcinoma: relationship to serum TSH levels. J Clin Endocrinol Metab 51:513-519

15. Ket JL, De Vijlder JM, Bikker H, Gons MH, Tegelaers WHH 1981. Serum thyroglobulin levels: the physiological decrease in infancy and the absence of athyroidism. J Clin Endocrinol Metab 53:1301-1303

16. Sauk JJ 1970. Ectopic lingual thyroid. J Pathol 102:239-243

17. Strickland AL, Macfie JA, Van Wyk JJ, French FS 1967. Ectopic thyroid glands stimulating thyroglossal duct cysts: hypothyroidism following surgical excision. JAMA 208:307-310

18. Conklin WT, Davis RM, Dabb RW, Reilly CM 1981. Hypothyroidism following removal of a "thyroglossal duct cyst." Plast Reconstr Surg 68:930-932

19. Penny R, Spencer CA, Frasier D, Nicoloff JF 1983. Thyroid-stimulating hormone and thyroglobulin levels decrease with chronological age in children and adolescents. J Clin Endocrinol Metab 56:177-180

20. Mariotti S, Martino E, Cupini C, Lari R, Giani C, Baschieri L, Pinchra A 1982. Low serum thyroglobulin as a clue to the diagnosis of thyrotoxicosis factitia. N Engl J Med 307:410-412 